\title{
A radio tracking study of home range and movements of the marsupial Micoureus demerarae (Thomas) (Mammalia, Didelphidae) in the Atlantic forest of south-eastern Brazil
}

\author{
Edsel Amorim Moraes Junior ${ }^{1,2} \&$ Adriano Garcia Chiarello ${ }^{1}$ \\ ${ }^{1}$ Conservation, Ecology and Animal Behaviour Group, Programa de Pós-graduação em Zoologia de Vertebrados, Pontifícia \\ Universidade Católica de Minas Gerais. Avenida Dom José Gaspar 500, Prédio 41, Coração Eucarístico, $30535-610$ Belo \\ Horizonte, Minas Gerais, Brasil.E-mail: edsel.bhz@terra.com.br; bradypus@pucminas.br \\ 2 Corresponding author.
}

\begin{abstract}
From August 2001 to July 2002 the home range and movements of seven Micoureus demerarae (Thomas, 1905) (three males and four females) were investigated using radio tracking in the União Biological Reserve, state of Rio de Janeiro, south-eastern Brazil. A total of 436 locations was obtained and home range estimated with fixed Kernel ( $95 \%$ of data points), and minimum convex polygon (MCP) methods, with 100 and $95 \%$ of data points. Male home ranges estimated by MCP (100\%) ranged from 5.4-24.2 ha and females from 0.3-10.7 ha. Corresponding figures calculated with Kernel (95\%) were 4-10.9 ha for males and 1.3-5.9 ha for females. Animals travelled on average $423 \mathrm{~m} /$ night, with males travelling significantly further $(582.8 \mathrm{~m} / \mathrm{night})$ than females (335.1 $\mathrm{m} /$ night) ( $\mathrm{t}$ test, $\mathrm{t}=3.609, \mathrm{p}=0.001$ ). We concluded that radio tracking produced much larger home ranges than those estimated with traditional live-trapping techniques, suggesting that the latter might underestimate ranging when the area covered with traps is relatively small (ca.1 ha or less). Radio tracking also indicated that $M$. demerarae, although predominantly arboreal and weighting only ca. 130 g., has movements similar in magnitude to larger-sized terrestrial didelphimorph marsupials, such as Didelphis Linnaeus, 1758, Philander Linnaeus, 1758 and Metachirus (Desmarest, 1817).
\end{abstract}

KEY WORDS. Kernel, minimum convex polygon, radio-telemetry, small mammals, travelling.

RESUMO. A radio tracking study of home range and movements of the marsupial Micoureus demerarae (Thomas) (Mammalia, Didelphidae) in the Atlantic forest of south-eastern Brazil. No período de agosto de 2001 a julho de 2002 a área de uso e o movimento de sete Micoureus demerarae (Thomas, 1905) (três machos e quatro fêmeas) foram acompanhados, através de rádio-telemetria, na Reserva Biológica União, Rio de Janeiro, sudeste do Brasil. Foi obtido um total de 436 localizações e estimou-se a área de uso através dos métodos Kernel fixo (95\% das localizações) e polígono mínimo convexo (PMC), com 100 e 95\% das localizações. A área de uso dos machos estimada pelo PMC (100\%) variou de 5,4-24,2 ha e fêmeas de 0,3-10,7 ha. Áreas calculadas com Kernel (95\%) foram 4-10,9 ha para machos e 1,3-5,9 ha para fêmeas. Os animais locomoveram em média $423 \mathrm{~m} /$ noite, com machos se deslocando mais $(582,8 \mathrm{~m} /$ noite) que as fêmeas $(335,1 \mathrm{~m} /$ noite) (Teste $\mathrm{t} ; \mathrm{t}=3,609 ; \mathrm{p}=0,001$ ). Concluímos que o rádio rastreamento proporcionou áreas de uso superiores ao de estudos tradicionais realizados com capturas em armadilhas, sugerindo que pode haver uma subestimativa quando a área coberta com armadilhas é relativamente pequena ( 1 ha ou menos). O rádio-rastreamento também indicou que $M$. demerarae, embora seja predominantemente arborícola e pesa cerca de $130 \mathrm{~g}$, possui movimentos semelhantes em magnitude a marsupiais terrestres de maior porte, como Didelphis Linnaeus, 1758, Philander Linnaeus, 1758 and Metachirus (Desmarest, 1817). PALAVRAS CHAVE. Kernel, pequenos mamíferos, polígono mínimo convexo, radio-telemetria.

The Didelphidae is one of the most diverse families among extant marsupials, but relatively little is known about the natural history of most species (NowaK \& PARADIso 1991). Micoureus demerarae (Thomas, 1905) is nocturnal with adults weighting about $130 \mathrm{~g}$. It is a highly mobile (CHARLEs-Dominique et al. 1981) insectivore-omnivore marsupial (Leite et al. 1994); Carvalho et al. 1999) with a predominantly arboreal habit, as demonstrated by previous studies (Charles-DominiQue et al. 1981, Miles et al. 1981, Stallings 1988, Fonseca \& Kierulff 1989, Passamani 1995, Pires \& Fernandez 1999). This specie is widely distributed, being encountered in South America, from Colombia south to Argentina (Emmons \& FeER 1997). Recent taxonomic revisions

Revista Brasileira de Zoologia 22 (1): 85-91, março 2005 
suggest that $M$. demerarae is, in fact, a group of seven distinct species, one of which endemic to the centre-south portion of the Atlantic forest (L.P. Costa personal communication). However, since true taxonomic status and nomenclature are still uncertain, we have used here the traditional name $M$. demerarae for this taxon, following GARDNER (1993).

Several studies have been conducted to quantify home range and movement patterns of small mammals, but the majority of these have relied upon the traditional technique of capture-mark-recapture using live traps placed in grids (PIrEs \& Fernandez 1999) or alternatively, using spool-and-line techniques (Miles et al. 1981). Radio tracking, however, is not constrained by limitations in trap numbers, the area covered by traps, or line length and weight. Therefore, it may provide a less biased estimate for important ecological parameters such as home range and movement patterns. With the exception of the study carried out by STALLings et al. (1994), there are no published results of home range and movement studies of Atlantic forest small mammals based on radio tracking, the main objective of this paper. These data are not only important for a better understanding of the natural history of this species but are also needed to guide conservation strategies of mammals increasingly confined to isolated forest remnants of the Atlantic forest (Conservation International do Brasil et al. 2000). As a second objective, this study compares results based on radio tracking with those obtained using more traditional techniques for small mammals, such as live-trapping.

\section{MATERIAL AND METHODS}

\section{Study area}

The study was carried out in União Biological Reserve (UBR), a 2,400 ha federal reserve administered by the Brazilian Environmental Agency (IBAMA) and located on the borders of Casimiro de Abreu and Rio das Ostras municipalities, in north Rio de Janeiro state, south-eastern Brazil $\left(22^{\circ} 27^{\prime} 36^{\prime \prime} S\right.$ and $\left.42^{\circ} 02^{\prime} 15^{\prime \prime} \mathrm{W}\right)$. The main vegetation type is dense ombrophilous forest (IвGв 1993). During the study period the annual rainfall was $1,138 \mathrm{~mm}$, with temperatures averaging $24.5^{\circ} \mathrm{C}$. The dry season occurs from April to September, and the wet season from October to March (LAPENTA et al. 2003).

\section{Data collection and analysis}

Data were collected from August 2001 to July 2002. Wild (and resident) individuals of Micoureus demerarae were captured using wire live-traps baited with banana and commercial cod liver oil ("Scott Emulsion"), placed 1-2 m above the ground or in tree platforms, following the methods of STALLINGS (1988) and Malcolm (1991). Thirty traps were left baited and opened four nights/month during one year, totalling 120 trap-nights per month and 1,440 trap-nights for the whole study. All traps were closed during radio-tracking to avoid influencing movement patterns of individuals being monitored (see below). Captured individuals were anaesthetised (ketamin $10 \mathrm{mg} / \mathrm{kg}$ ) and fitted with Wildlife Materials Inc. (model SOM-2190) radio collars. These collars weighted on average $3.5 \mathrm{~g}$, which represents less than $5 \%$ of the adult weight of $M$. demerarae and were, therefore, within the weight limits recommended not to disturb the natural behaviour of mammals (COCHRAN 1969). Every marked individual was radio-tracked during four full nights (1800-0600 h) per month, until the death of the animal (natural or predation) or battery exhaustion/equipment failure. A Telonics receiver (model TR-2; frequency: 164-165 MHz), a three-element Yagi antenna and headphones were used for radio tracking. Positions of marked individuals were calculated through triangulation, recording a minimum of three azimuths of each animal every 60 minutes during observation nights. Azimuths were recorded at $<5$ min intervals at distances $<150$ $\mathrm{m}$ from monitored (radio-collared) individuals. These positions were used to calculate the individual's position using the software Locate II (version 1.6, Pacer, Canada). When possible, sleeping places of marked individuals were located and their position mapped. Locations in UTM (Universal Transverse Mercator) coordinates of each marked animal were plotted on scaled (1: 10,000) maps of the area. These data were then analysed using Animal Movement Analyst Extension (AMAE) version 2.0 (Hooge et al. 1999) for Arcview 3.2 (Environmental Systems Research Institute, ESRI, Redlands, California, USA).

For comparative purposes, home ranges were calculated using two methods: the minimum convex polygon ("MCP") (Mohr 1947), and fixed Kernel ("KER") (WorTon 1989). Home ranges calculated with the MCP used either $100 \%$ of locations (to allow comparisons with other studies) or $95 \%$ of locations, in which the most peripheral points (outliers) were excluded. As pointed out by White \& GARROT (1990) using outliers can greatly overestimate home range size, including parts never visited by the individuals. For the same reason $95 \%$ of locations were used to calculate accurate home ranges with Kernel. A fixed Kernel was used with bandwidth (" $h$ ") chosen as $30 \mathrm{~m}$, as indicated by AMAE software and in accordance with what is believed to be the perception radius of this species (Powell 2000). Location error was calculated measuring the area of an ellipse formed by the intersection of the three azimuths. Only those location points with an error (ellipse) area $<0.09$ ha were considered valid, and included in the analyses. For each marked individual a cumulative curve of home range in relation to monitoring time was constructed, using for these home range estimates based on MCP (100\%), following HARRIS et al. (1990). We understand that locations collected every 60 minutes might not be considered by some as truly independent observations. We however, agree with other authorities in that sample size is more important than autocorrelation of data points, especially when Kernel is used to estimate a home range (Reynolds \& LaUndRe 1990, MinTa 1992, McNay et al. 1994, Oтіs \& Whiте 1999). We decide, therefore, do not discard important and hard to get biological information in order to accurately map home range details of the study animal. 


\section{RESULTS}

A total of 436 valid locations of seven adult individuals (four females and three males), monitored during periods lasting from one to five months, were recorded (Tab. I). Interruptions to specific monitoring periods were due to the following circumstances: two individuals were preyed upon (MD-OM and $\mathrm{MD}-2 \mathrm{~F}$ ); the radio-collar of three others stopped working (MD$3 \mathrm{M}$ and $\mathrm{MD}-5 \mathrm{M}$ ); one did not function properly (MD-1F); and one individual removed its radio-collar (MD-4F). Thus, only one individual (MD-6F) had to be recaptured at the end of the field study to retrieve its collar and release it back into the forest. The home range of female MD-1F showed stabilization around 100 locations (Fig. 1); for the other females the number of locations was too small to allow strong inference about home range stabilization. Of the three monitored males, two
(MD-0M and MD-5M) reached an asymptote after 40 locations (Fig. 1). In general, home ranges were larger for males than for females (Tab. II) but small sample size hampered statistical comparison between sexes. Using all valid locations (MCP $100 \%$ ) the home range of males varied from 5.4 to 24.2 ha and females's from 0.3-10.7 ha. Kernel and MCP (both with 95\% of valid locations) produced comparable estimates for Males MD-0M and MD-5M and for the female MD-1F, the better sampled individuals. For the remaining, differences between these two methods were higher (Tab. II). Kernel (95\%) allowed visualization of the intensity with which each animal used its home range (Figs 2 and 3). Intensively used areas were close to or coincided with nests or resting sites. It was also noticed that home ranges of males had, in general, more than one intensively used area (Fig. 2), while home range of females were more concentrated around a single area (Fig. 3).
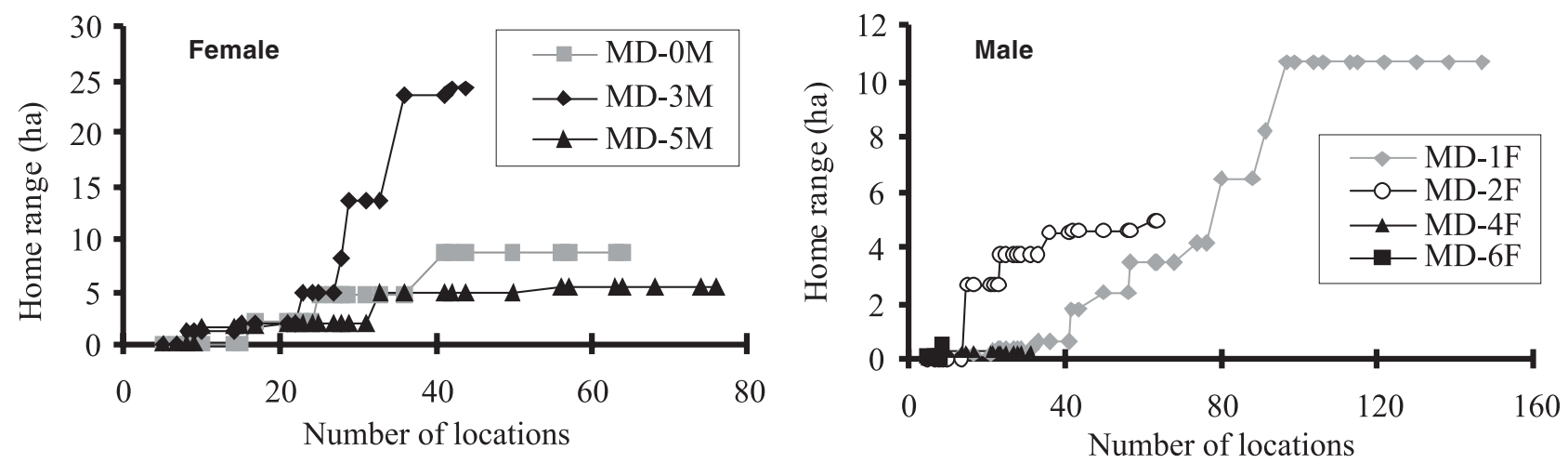

Figure 1. Cumulative curves of home range areas plotted against number of locations for females (A) and males (B). Areas were calculated using Minimum Convex Polygon Method (100\%).

Table I. Number of sampled nights, locations recorded and monitoring period for seven radio-tracked Micoureus demerarae in União Biological Reserve, south-eastern Brazil.

\begin{tabular}{|c|c|c|c|c|c|c|c|c|c|c|c|c|c|c|}
\hline & \multirow{2}{*}{$\begin{array}{l}\text { Number } \\
\text { of nights }\end{array}$} & \multirow{2}{*}{$\begin{array}{c}\text { Number of } \\
\text { locations }\end{array}$} & \multicolumn{5}{|c|}{2001} & \multicolumn{7}{|c|}{2002} \\
\hline & & & A & $S$ & $\mathrm{O}$ & $\mathrm{N}$ & $\mathrm{D}$ & J & $\mathrm{F}$ & $M$ & A & $M$ & $J$ & $J$ \\
\hline \multicolumn{15}{|l|}{ Males } \\
\hline MD-0M ${ }^{a}$ & 4 & 64 & & & & & & & & & & & & \\
\hline$M D-3 M^{b}$ & 6 & 43 & & & & & & & & & & & & \\
\hline$M D-5 M^{b}$ & 7 & 76 & & & & & & & & & & & & \\
\hline \multicolumn{15}{|l|}{ Females } \\
\hline MD-1F ${ }^{b}$ & 18 & 147 & & & & & & & & & & & & \\
\hline $\mathrm{MD}-2 \mathrm{~F}^{\mathrm{a}}$ & 6 & 66 & & & & & & & & & & & & \\
\hline $\mathrm{MD}-4 \mathrm{~F}^{\mathrm{c}}$ & 3 & 31 & & & & & & & & & & & & \\
\hline MD-6F d & 4 & 9 & & & & & & & & & & & & \\
\hline Total & 48 & 436 & & & & & & & & & & & & \\
\hline
\end{tabular}

Circumstances/fate of individuals that caused end of monitoring time: (a) individual preyed upon (carcass and collar found on the ground); (b)radio-collar failure; (c) individual apparently managed to remove the collar (collar found on the ground); (d) individual recaptured to retrieve collar after end of field study. 


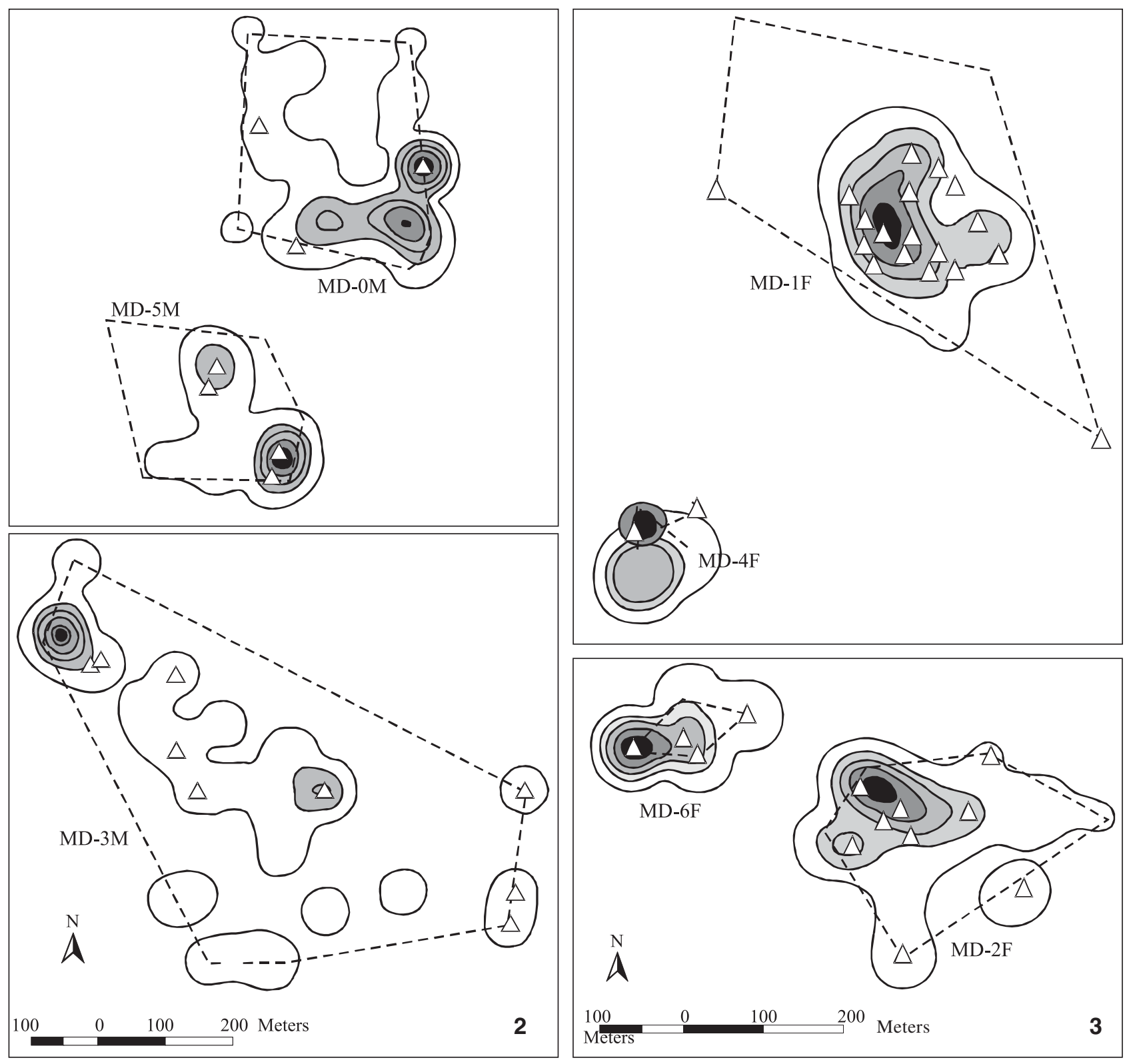

Figures 2-3. Home ranges of: (2) males MD-0M and MD-5M (above) and MD-3M (below) and (3) females MD-1F and MD-4F (above) and MD-2F and MD-6F (below), calculated by Minimum Convex Polygon method (100\%) (straight lines), and fixed Kernel method (contour lines). Concentric contours indicate intensity of use, ranging from 95\% (most external contours) to 5\% (most internal contour line). Location of nests or daily resting places are indicated by triangles.

As shown in figure 4, there was no home range overlap among males, however, home range of females overlapped between and were contained within home ranges of males. It is important to note that animals were monitored in different time periods and, therefore, not all observed overlaps were, in fact, recorded contemporaneously. For example, home range of the female MD-1F only included the home range of $\mathrm{MD}-2 \mathrm{~F}$ after the latter was found dead (its carcass showed signs indicating predation). Similarly, the female MD-6F was only captured within the area of the other female MD-1F four months after the last contact (radio signal) with MD-1F. Nevertheless, overlapping between the male MD-3M and the female MD-1F was recorded contemporaneously.

Marked individuals moved, on average, $423 \mathrm{~m} / \mathrm{night}$

Revista Brasileira de Zoologia 22 (1): 85-91, março 2005 


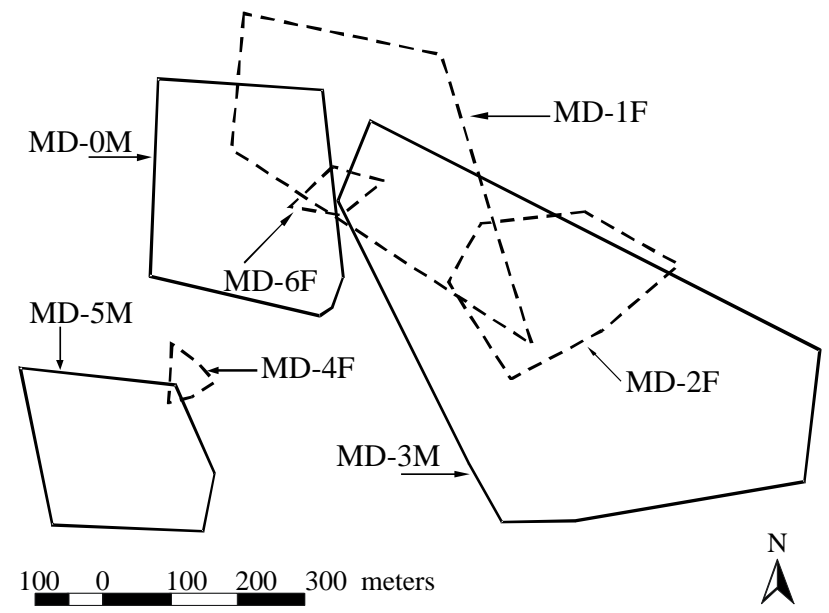

Figure 4. Home ranges of seven Micoureus demerarae in União Biological Reserve, south-eastern Brazil, calculated using the Minimum Convex Polygon method (100\%). Males are indicated by continuous lines and females by dashed lines.

Table II. Number of locations and home ranges of seven $M$. demerarae calculated using minimum convex polygon (MCP) and Kernel estimators.

\begin{tabular}{|c|c|c|c|c|c|}
\hline \multirow{2}{*}{ Individuals } & \multirow{2}{*}{ Gender } & \multirow{2}{*}{$\begin{array}{c}\text { Number of } \\
\text { locations }\end{array}$} & \multicolumn{2}{|c|}{ MCP } & \multirow{2}{*}{$\begin{array}{l}\text { Kerne } \\
(95 \%)\end{array}$} \\
\hline & & & $100 \%$ & $95 \%$ & \\
\hline MD-OM & male & 64 & 8.5 & 7.1 & 7.3 \\
\hline MD-3M & male & 43 & 24.2 & 21.1 & 10.9 \\
\hline MD-5M & male & 76 & 5.4 & 3.2 & 4.0 \\
\hline MD-1F & female & 145 & 10.7 & 3.6 & 4.6 \\
\hline MD-2F & female & 66 & 5.0 & 4.3 & 5.9 \\
\hline MD-4F & female & 31 & 0.3 & 0.1 & 1.3 \\
\hline MD-6F & female & 9 & 0.5 & 0.5 & 2.4 \\
\hline
\end{tabular}

(range $=34-1,140 \mathrm{~m} /$ night) (Tab. III) but significant differences were detected between individuals (ANOVA; $F_{[5,41]}=7.750, p<$ 0.001 ). Males and females al so differed significantly (t Test; $t=$ $3.609, \mathrm{p}=0.001$ ), with males ranging, on average, $583 \mathrm{~m} / \mathrm{night}$ (S.E. $=53 \mathrm{~m}$; range $=317-1,097 \mathrm{~m} / \mathrm{night}$ ) and females $335 \mathrm{~m} /$ night (S.E. $=47 \mathrm{~m}$; range $=34-1,104 \mathrm{~m} /$ night).

\section{DISCUSSION}

The relative stabilization of cumulative home ranges for males MD-0M and MD-5M and for females MD-1F and MD-2F indicate that these estimates can be considered good approximations of true home ranges (HarRIS et al. 1990). However, even for the individuals with high number of locations, home ranges here reported should be considered as underestimates of the true areas since they were calculated after monitoring periods lasting less than one full year. It is likely, therefore, that longer
Table III. Sample size (N) and average distance travelled/night of seven radio-tracked $M$. demerarae in União Biological Reserve, south-eastern Brazil. Standard error (S.E.) and range of distances are also shown.

\begin{tabular}{|c|c|c|c|c|c|}
\hline \multirow{2}{*}{ Individual } & \multirow{2}{*}{ Gender } & \multirow{2}{*}{$\mathrm{N}$} & \multicolumn{3}{|c|}{ Distance travelled/night (m) } \\
\hline & & & Mean & S.E. & Range \\
\hline MD-OM & male & 4 & 850 & 146 & $491-1,097$ \\
\hline MD-3M & male & 6 & 472 & 56 & $323-641$ \\
\hline MD-5M & male & 7 & 525 & 60 & $317-679$ \\
\hline MD-1F & female & 18 & 335 & 56 & $34-1,140$ \\
\hline MD-2F & female & 6 & 575 & 120 & $265-1,068$ \\
\hline MD-4F & female & 3 & 198 & 60 & $85-288$ \\
\hline MD-6F & female & 4 & 78 & 6 & $61-$ \\
\hline Total & & 48 & 423 & 40 & $34-1,140$ \\
\hline
\end{tabular}

periods of monitoring would produce even larger home ranges.

The Kernel method was considered to produce the best estimates for home ranges. Besides giving excessive emphasis on external points, ignoring any location information recorded within the perimeter of the polygon, the MCP method might include several localities never actually used or passed by the individual, thus overestimating its home range (KENWARD 2001, Kernoham et al. 2001). On the other hand, the Kernel method did show areas more intensively used by the animal, illustrating its internal structure. According to KerNoham et al. (2001), this method offers several advantages: it produces accurate estimates even with location numbers as small as 30; it is less sensitive to lack of independence between locations; it allows for morethan one center of activity and is less influenced by external points (KeRNOHAM et al. 2001). Additionally, the use of programs such as GIS (Geographic Information System) like AM AE for ArcView, greatly improves results due to the high precision with which these programs work (SELKIRK \& BISHOP 2002).

It is known that, everything else being equal, larger individuals have larger ranges than smaller individuals because the former need higher absolute amounts of energy and, consequently, have to move greater distances in order to find enough food to satisfy their needs ( $M_{C} N_{A B}$ 1963). This may explain why males had larger home ranges than females in this study, since males were heavier (130 g) than females (103 g). An alternative explanation is that in Micoures demerarae only females seem to be territorial (PIRES et al. 1999, PIRES \& FERNANDEZ 1999). If that is really the case, the territory of a female might represent a barrier to the movement of other females, thus restricting their home ranges. The females MD-1F and MD-2F, for example, were monitored simultaneously during September, a period with no overlap between their ranges; the individual MD-1F only "invaded" the homerange of MD-2F after thelater was preyed upon. However, the contemporaneous overlapping between ranges of MD-3M and MD-1F suggest that males have larger ranges because they might monitor/mate with more than one female. 
In another study of M. demerarae in south-eastern Brazil (Poço das Antas Biological Reserve, state of Rio de Janeiro), Pires \& Fernandez (1999) estimated home ranges of 0.10-2.45 (males) and 0.10-1.10 ha (females), considering all captures and recaptures of each individual. That study was carried out in a fragmented region where forest remnants are small (1.2 to 13.3 ha in size). It is difficult to believe that differences in ecological parameters, such as forest structure and food resources, might account for the huge discrepancies observed in home range among study sites, which were located in similar floristic and climatic areas of Atlantic forest regions. It seems more reasonable to conclude, therefore, that these differences are rather due to the different methods used and that live trapping might underestimate home range of some species when trap grids cover relatively small areas.

Studies about the movements of small mammals have been conducted using several techniques (Miles et al. 1981), however, for the Atlantic forest Micoureus demerarae this is the first study using radio tracking. MiLes et al. (1981) calculated an average distance of $603 \mathrm{~m} /$ night for three captured individuals of Marmosa cinerea ( = Micoureus demerarae), a figure similar to the average distances traversed by males in the present study. PIREs et al. (2002) observed movements of up to $860 \mathrm{~m} /$ day for this species in the Atlantic forest fragments of Poço das Antas Biological Reserve. The larger movement detected in the present study was $1,140 \mathrm{~m}$, similar in magnitude to Didelphis marsupialis Linnaeus, 1758 movements recorded by SunQuist et al. (1987). Using spool-and-line, Miles et al. (1981) recorded nocturnal averages of $801 \mathrm{~m}, 506 \mathrm{~m}$ and $438 \mathrm{~m} / \mathrm{night}$ for D. marsupialis, Metachirus nudicaudatus (Desmarest, 1817) and Philander opossum Linnaeus, 1758 respectively. These figures indicate that Micoureus demerarae move equivalent distances to larger-bodied species of marsupials. The high moving capacity of this species is even more impressive when one considers that the other three marsupial species mentioned move mostly on the ground, whereas $M$. demerarae is predominantly arboreal. Arboreal species of marsupials have high rates of metabolism (EISENBERG \& WiLSON 1981); as a consequence, it is likely that the observed high level of activity and long distances travelled are results of the species need to find enough food to satisfy its relatively high demand for energy.

PIREs et al. (2002) recorded four movements of males of this species between isolated fragments. Due to the low frequency of observed movements (recorded via capture-mark-recapture), these authors remarked that subpopulations of each forest fragment are not completely isolated from each other, rather, they function like a true metapopulation (i.e., subpopulations linked by dispersing individuals). In the present study both male (MD-3M) and female (MD-2F) were observed to use a grassland area. These results, together with the large home ranges here reported for the species, indicate that Micoureus demerare is much wider ranging than previously thought. As a consequence, some movements attributed to dispersion might simply be due to foraging. Therefore, it is recommended that future studies back live-trapping results with telemetry data, as this approach would allow not only a better understanding of home range dynamics but also a more precise analysis of forest fragmentation effects. This approach would facilitate, for example, knowledge on how truly isolated subpopulations of this marsupial are, when inhabiting forest remnants surrounded by grassland or agriculture. On what frequency males and females venture themselves outside forest fragments? What distances are they able to cross in areas dominated by pastures and other open vegetation types? Do they perform this routinely or are these movements really due to dispersion? These and other questions were still not adequately answered, but nevertheless they are essential to the conservation of Micoureus demerarae as well as other species of small mammals of the Atlantic forest.

\section{ACKNOWLEDGEMENTS}

We wish to thank the Golden-Lion-Tamarin Association for logistic and financial support. We are also grateful to the biologist Paula Procópio Oliveira and the whole team of liontamarin translocation program (Programa de Translocação do Mico-Leão-Dourado). IDEA WILD donated some of the equipment used, and the Brazilian Program CAPES provided a postgraduate studentship for one of us (E.A.M.J.). The Brazilian Environmental Agency (IBAMA) provided research licenses, and staff of União Biological Reserve, especially its director Whitson José da Costa Júnior, were very helpful during field work. Flávio H.G. Rodrigues and Yuri L.R. Leite made substantial comments on an early draft of the manuscript and Robert Young kindly reviewed the English.

\section{REFERENCES}

Carvalho, F.M.V.; P.S. Pinheiro; F.A.S. Fernandez \& J. Nessiman. 1999. Diet of small mammals in Atlantic Forest fragments in southern Brazil. Revista Brasileira de Zoociências, Juiz de Fora, 1: 91-101.

Charles-Dominique, P.; M. Atramentowicz; M. Charles-Dominique; H. Gerárd; A. Hladick; C.M. Hladik, \& M. Prevóst. 1981. Les mammiferes frugivores arborícoles nocturnes d'une forest guyanaise: Inter-relations plantes-animaux. Revue d'Ecologie Terre et la Vie, Paris, 35: 341-435.

Cochran, W.W. 1969. Wildlife telemetry, p. 507-520. In: R.H. GiLes JR. (Ed). Wildlife Management Techniques Manual. Washington., Wildlife Society, 623p.

Conservation International do Brasil, Fundação sos Mata Atlântica, Fundação Biodiversitas, Instituto de Pesquisas Ecológicas, Secretaria do Meio Ambiente do estado de São Paulo and SEMAD/Instituto Estadual de Florestas-MG. 2000. Avaliação e ações prioritárias para a conservação da biodiversidade da Mata Atlântica e Campos Sulinos. Brasília, Ministério do Meio Ambiente/MMA, 40p.

Emmons, L.H. \& F. FeEr. 1997. Neotropical Rainforest Mammals:

Revista Brasileira de Zoologia 22 (1): 85-91, março 2005 
A field guide. Chicago, The University of Chicago Press, XVI+307p.

EINSENBERG, J.F. \& D.E. Wilson. 1981. Relative brain size and demographic strategies in didelphid marsupials. American Naturalist, Chicago, 118: 1-15.

FonseCA, G.A.B. \& M.C.M. KierulfF. 1989. Biology and natural history of Brazilian Atlantic Forest small mammals. Bulletin of Florida Museum of Natural History, Gainesville, 34: 99-152.

GARDNER, A.L. 1993. Order Didelphimorphia, p. 15-24. In: D.E. WiLSON \& D.M. REEDER (Eds). Mammal species of the World: A taxonomic and geographic reference. Washington, Smithsonian Institution Press, 1312p.

Harris, S.; W.J Cresswell; P.G. Forde; W.J. Trewhella; T. Woollard \& S. Wray. 1990. Home-range analysis using radio-tracking data - a review of problems and techniques particularly as applied to the study of mammals. Mammalian Review, London, 20: 97-123.

Hooge, P.N.; W. Eichenlaub, \& E. Solomon. 1999. The Animal Movement Program version 2.0 Beta. Anchorage, Alaska Biological Science Center, U.S. Geological Survey.

IbGe, 1993. Mapa de vegetação do Brasil. Rio de Janeiro, Fundação Instituto Brasileiro de Geografia e Estatística.

Kenward, R.E. 2001. A Manual for Wildlife Radio Tagging. San Diego, Academic Press, 311p.

Kernoham, B.J.; R.A. Gitlen \& J.J. Millspaugh. 2001. Analysis of animal space use and movements, p. 125-166. In: J.J. MilLsPaugh \& J.M. Marzluff (Eds). Radio Tracking and Animal Populations. San Diego, Academic Press, 474p.

Lapenta, M.J.; P.P. Oliveira; M.C.M. KierulfF \& J.C. Motta-Junior. 2003. Fruit exploitations by Golden Lion Tamarins (Leontopithecus rosalia) in the União Biological Reserve, Rio das Ostras, RJ - Brazil. Mammalia, Paris, 67: 41-46.

Leite, Y.L.R.; J.R. Stallings \& L.P. Costa. 1994. Partição de recursos entre espécies simpátricas de marsupiais na Reserva Biológica de Poço das Antas, Rio de Janeiro. Revista Brasileira de Biologia, Rio de Janeiro, 54: 525-536.

Malcolm, J.R. 1991. Comparative abundances of Neotropical small mammals by trap height. Journal of Mammalogy, Provo, 72: 188-192.

MCNAB, B.K 1963. Bioenergetics and the determination of home range size. American Naturalist, Chicago, 97: 133-140.

MacNay, S.R. J.A. Morgan \& F.L. Bunnell. 1994. Characterizing independence of observations in movements of Columbian black-tailed deer. Journal Wildlife Management, Madison, 58: 422-429.

Miles, M.A.; A.A. Souza \& M.M. Povoa. 1981. Mammal tracking and nest location in Brazilian forests with an improved spool-and-line device. Journal Zoology London, Cambridge, 195: 331-347.

MINTA, S.C. 1992. Tests of spatial and temporal interaction among animals. Ecological Applications, Ann Arbor, 2: 178-188.

МонR, C.O. 1947. Table of equivalent populations of North
American small mammals. American Midland Naturalist, Notre Dame, 37: 223-249.

NoWAK, R.M \& J.L. PARADISO. 1991. Walker's mammals of the world. Baltimore, Johns Hopkins University Press, vol. 1, $5^{\text {th }}$ ed., 642 p.

Otis, D.L. \& G.C. Whiтe. 1999. Autocorrelation of location estimates and the analyses of radio-tracking data. Journal Wildlife Management, Madison, 63: 1039-1044.

Passamani, M. 1995. Vertical stratification of small mammals in Atlantic hill forest. Mammalia, Paris, 59: 276-279.

Pires, A.S. \& F.A.S. Fernandez. 1999. Use of space by the marsupial Micoureus demerarae in small Atlantic Forest fragments in south-eastern Brazil. Journal of Tropical Ecology, Cambridge, 15: 279-290.

Pires, A.S.; F.A.S. Fernandez \& D. De Freitas. 1999. Patterns of space use by Micoureus demerarae (Marsupialia: Didelphidae) in a fragment of Atlantic forest in Brazil. Mastozoologia Neotropical, Mendoza, 6: 39-45.

Pires, A.S.; P.K. Lira; F.A.S. Fernadez; G.M. Schittini. \& L.C. OliVEIRA. 2002. Frequency of movements of small mammals among Atlantic Coastal Forest fragments in Brazil. Biological Conservation, Paris, 108: 229-237.

Powell, R.A. 2000. Animal home ranges and territories and home range estimators, p. 65-110. In: L.BOITANI \& T.K. FULLEN (Eds). Research Techniques in Animal Ecology Controversies and Consequences. New York, Columbia University Press. 442p.

Reynolds, T.D. \& J.W. Laundre. 1990. Time intervals for estimating pronghorn and coyote home ranges and daily movements. Journal Wildlife Management, Madison, 54: 316-322.

SELKIRK, S.W. \& I.D. BISHOP. 2002. Improving and extending home range and habitat analysis by integration with a Geographic Information System. Transactions in GIS, Edinburgh, 6: 151-159.

STALLINGS, J.R. 1988. Small mammal inventories in an eastern Brazilian park. Bulletin of Florida Museum of Natural History, Gainesville, 34: 153-200.

Stallings, J.R.; M.C.M. Kierulff \& L.F.B.M. Silva. 1994. Use of space, and activity patterns of Brazilian bamboo rats (Kannabateomys amblyonyx) in exotic habitat. Journal of Tropical Ecology, Cambridge, 10: 431-438.

Sunquist, M.E.; S.N. Austad \& F. Sunquist. 1987. Movement patterns and home range in the opossum (Didelphis marsupialis) Journal of Mammalogy, Provo, 68: 173-176.

White, G.C. \& R.A. Garrot. 1990. Analysis of Wildlife Radiotracking Data. New York, Academic Press. 383p.

Worton, B J. 1989. Kernel methods for estimating the utilization distribution in home range studies. Ecology, Washington D.C., 70: 164-168.

Received in 18.V.2004; accepted in 13.I.2005. 